\title{
Glottic Cancer pM1 TNM Finding v6 and v7
}

National Cancer Institute

\section{Source}

National Cancer Institute. Glottic Cancer pM1 TNM Finding v6 and v7. NCI Thesaurus.

Code C64682.

Glottic cancer with distant metastasis. (from AJCC 6th and 7th Eds.) 